\title{
The Authority of the Civil Service Police Unit in Handling Beggars, Vagabonds and Derelicts in Kuningan District, Indonesia
}

\author{
Igit Wijaya Susanto and Erga Yuhandra \\ Faculty of Law, University of Kuningan, Indonesia \\ Email: wijayaigit96@gmail.com
}
How to cite : Susanto, Igit Wijaya; Erga Yuhandra. (2018). The Authority of the Civil Service Police Unit in Handling Beggars, Vegabonts and Derelicts in Kuningan District, Indonesia . UNIFIKASI : Jurnal Ilmu Hukum, 5(2), 125-132. DOI : 10.25134/unifikasi.v5i2.916 Submitted : 31-03-2018 Revised : 21-04-2018 Accepted : 20-08-2018

\begin{abstract}
Beggars, vagabonds and derelicts (PGOT) need to be disciplined by the government in order to maintain public orderliness and peace. The purpose of this research is to analyze the authority of the Civil Service Police Unit in handling beggars, vagabonds and derelicts based on Regional Regulation Number 03 of 2015 and the factors inhibiting the Civil Service Police Unit in handling beggars, vagabonds and derelicts in Kuningan District. The method used in this research was an empirical juridical approach by using primary and secondary data in which the data were collected through field and literary studies. The results showed that the authority of the Civil Service Police Unit in handling beggar, vagabonds and derelicts based on Regional Regulation Number 03 of 2015 is as an organizer of public orderliness and peace related to social orderliness as stipulated in Article 28-30; and the factors inhibiting the Civil Service Police Unit in handling PGOT in Kuningan District, namely internal and external factors, such as PGOT knows when the Civil Service Police Unit's car comes to discipline them, PGOTs are repeatedly raided, lack of APBD funds, and there is no shelter for PGOT. In conclusion, it is proved that the authority of the Civil Service Police Unit in handling PGOT based on Regional Regulation Number 03 of 2015 concerning public orderliness and peace is repressive where the discipline actions are only in the form of non-judicial acts towards beggars, vagabonds and derelicts.
\end{abstract}

Keywords: Authority, the Civil Service Police Unit, Handling, Beggars, vagabonds and derelicts.

\section{Kewenangan Satuan Polisi Pamong Praja dalam Penanganan Pengemis, Gelandangan dan Orang Terlantar di Kabupaten Kuningan, Indonesia}

\begin{abstract}
Abstrak : Pengemis, Gelandangan dan Orang Terlantar merupakan tangungjawab pemerintah dalam menertibkan sehingga tidak menggangu ketertiban umum serta kenyamanan masyarakat. Tujuan penelitian yaitu untuk mengetahui dan mengkaji bagaimana kewenangan Satuan Polisi Pamong Praja dalam penanganan masalah pengemis, gelandangan dan orang terlantar berdasarkan Peraturan Daerah Nomor 03 Tahun 2015 dan faktorfaktor apa saja yang menjadi penghambat Satuan Polisi Pamong Praja dalam penanganan pengemis, gelandangan dan orang terlantar di Kabupaten Kuningan. Metode yang digunakan dalam penelitian ini adalah dengan pendekatan yuridis empiris dengan menggunakan data primer dan data sekunder serta alat pengumpul data yang digunakan melalui studi lapangan dan studi kepustakaan. Hasil penelitian menunjukkan kewenangan Satuan Polisi Pamong Praja dalam penanganan masalah pengemis, gelandangan dan orang terlantar berdasarkan Peraturan Daerah Nomor 03 Tahun 2015 adalah sebagai penyelenggara ketertiban umum dan ketentraman masyarakat berkaitan dengan ketertiban sosial sebagaimana diatur dalam Pasal 28-30; dan faktor-faktor yang menjadi penghambat Satuan Polisi Pamong Praja dalam penanganan PGOT di Kabupaten Kuningan yaitu faktor internal dan eksternal PGOT berupa mengetahui ketika mobil Satpol PP datang untuk menertibkannya, PGOT berulang kali terjaring razia, kurangnya dana APBD, dan tidak adanya tempat penampungan bagi PGOT yang terjaring. Kesimpulan dari penulisan skripsi ini adalah kewenangan Satuan Polisi Pamong Praja dalam penanganan PGOT berdasarkan Peraturan Daerah Nomor 03 Tahun 2015 tentang Ketentraman dan Ketertiban Umum hanya bersifat represif yaitu hanya tindakan berupa penertiban nonyustisial terhadap pengemis, gelandangan, dan orang terlantar. Kata Kunci : Kewenangan, Satpol PP, Penanganan, Pengemis, Gelandangan dan Orang Terlantar.
\end{abstract}

\section{INTRODUCTION}

Globalization is a phenomenon where countries in the world directly or indirectly expect an interaction between societies that is far more effective and efficient compared to previous times. Like two sides of a coin, the phenomenon of globalization promises a much better environment and atmosphere of society life, but, on the other hand, there is also the potential for chaos if these changes are not managed properly. It is because, at an extreme point, an individual in a country can do 
whatever he wants (for example trading, partnering, collaborating, committing crime, colluding, etc.) with individuals in other countries. Therefore, it is clear that people's lives should be more organized in a system guarantying that the country will benefit greatly in the global environment, not the other way around. In the era of globalization, it increasingly shows its importance when the autonomy is started to be applied through Law Number 23 of 2014 concerning Regional Government. In this situation, all government sectors are needed in terms of creating a good governance system. One of the institutions playing a significant role in supporting the creation of good governance principles within the Regional Government is the Civil Service Police Unit.

In relation to the existence of the Civil Service Police Unit in law enforcement, as a part of regional government, the contribution of the Civil Service Police Unit is indispensable to support the successful implementation of regional autonomy in the enforcement of local regulations to create good governance. Thus, the Civil Service Police Unit is the front line in terms of motivators in ensuring the implementation of regional regulations and efforts to uphold them in the midst of the society as well as taking an action against all forms of fraud in law enforcement.

The Regional Head has the obligation to uphold legislations and maintain public orderliness and peace. Orderliness is a condition referring to society's regulations according to the prevailing norms which motivate ones to work in order to achieve the expected goals. ${ }^{1}$ The duty of the Regional Head does not only come from his own initiative, but it can also be ordered by a higher authority or what is called a co-administration task. ${ }^{2}$

Carrying out the authority to enforce regional regulations and the regional head's decisions, as one of the main tasks of the Civil Service Police Unit, is not an easy task especially the Civil Service Police Unit is limited by non-judicial repressive authority in carrying out this authority. Civil Service Police officers often have to face various obstacles when dealing with people who have particular

Dirjen Pemerintahan Umum, Pedoman Prosedur Tetap Operasional Satuan Polisi Pamong Praja, Departemen Dalam Negeri, Jakarta, 2005, ppl. 9.

Irawan Soejito, Sejarah Daerah Indonesia, Pradanya Paramita, Jakarta, 2010, pp. 100 interests in their lives which ultimately lead to the emergence of conflicts (clashes).

In dealing with this situation, the Civil Service Police should be able to take the right and wise stance, in accordance with the new paradigm of the Civil Service Police, namely becoming officers who are friendly and able to create an inner atmosphere for the society, but still firm in upholding applicable regulations.

With the issuance of Law Number 23 of 2014 concerning Regional Government, Article 255 Paragraph (1) states that the Civil Service Police are designated as the regional government apparatus with the main tasks of upholding regional regulations and maintaining public orderliness and peace as executors of decentralization. Decentralization is a way of governance where a portion of the power to regulate and administer from the central government is handed over to subordinate powers. ${ }^{3}$ Basically, each region has two types of power, namely autonomy and medebewind. ${ }^{4}$ Autonomy is the right to regulate and manage its own household, while medebewind is the right to carry out the regulations of the central or regional government based on orders. ${ }^{5}$

The existence of the Civil Service Police Unit in Kuningan District, especially in carrying out its duties, is regulated in Kuningan District Regulation Number 3 of 2015 concerning the Implementation of Public Orderliness and Peace, including the handling of beggars, vagabonds and derelicts (PGOT). In relation to the problems arising in the enforcement of regional regulations in Kuningan District, the apparatus assigned to maintain public orderliness and peace as well as society protection and enforcement of regional regulations and regional head's decisions are the Civil Service Police Unit.

The Civil Service Police of Kuningan District in its role of maintaining public orderliness and peace is very helpful. The Civil Service Police Unit can take a position appropriately and wisely when dealing with the society so that a friendly apparatus can be realized, but they remain firm in acting in

Hazairin, Otonomi dan Ketatanegaraan (dalam Ceramah Kongres III Serikat Sekerja Kementrian dalam Negeri, Bogor, 3-5 Desember 1953, dimuat dalam buku 7 Tahun Serikat Sekerja. Kementerian Dalam Negeri (SSKDN), 2004, pp. 160.

4 Wojowasito, Kamus Umum Belanda Indonesia, PT Ichtiar Baru Van Hoeve, Jakarta, 2003, pp. 80 \& 397.

The Liang Gie, Pertumbuhan Pemerintahan Daerah di Republik Indonesia, Liberty, Yogyakarta, 2007, pp. 99. 
accordance with applicable regulations. Thus, good governance can then be realized. Based on the description above, the problems can be formulated as follows: What is the authority of the Civil Service Police Unit in handling PGOT problems based on Regional Regulation Number 03 of 2015? What factors inhibiting the Civil Service Police Unit in handling PGOT in Kuningan Regency?

\section{METHOD}

The research method used is descriptiveexplorative with an empirical juridical approach. Here, literary and field studies are done to collect the data needed. Then, primary and secondary data are used as the data sources. The data collection tools which are used include field notes, history lists, checklists, or case studies of the existing phenomena. This research applies qualitative data analysis.

\section{RESULTS AND DISCUSSION}

\section{The authority of the Civil Service Police Unit} in Handling Beggars, Vagabonds and Derelicts in Kuningan District

Legislation is a guideline in implementing the rules to achieve the expected goals of the nation as it is stated in Article 1 paragraph (3) of the 1945 Constitution of the Republic of Indonesia that Indonesia is the state of law. The state of law is a country that upholds law to enforce truth and justice and there is no unaccountable power. Therefore, Indonesia as the state of law means that all actions of the state, which in this case are carried out by the government and its apparatus, should be based on the law. The conception of a constitutional state can be referred to the purpose of the state which is to protect the entire Indonesian nation and all of Indonesia's bloodshed, promote public welfare, educate the nation's life, and realize social justice. It is a country that stands above the law and guarantees justice to its citizens. Justice is a condition for society's happiness to live and it needs to be taught to every human being to become a good citizen. ${ }^{6}$

According to Aristotle, ones who rule the country are not actually human but a just mind, while the rulers are actually only a holder of law and balance. Decency will then determine a good or bad legislation and law-making is part of the ability to run a government. Therefore,

Moh. Kusnardi dan Harmaily Ibrahim, Hukum Tata Negara Indonesia, Sinar Bakti, Jakarta, 2009, pp.120. educating humans to be good citizens is a need because their fair behavior will then guarantee the citizens' happiness. ${ }^{7}$ Generally, in every country adhering to the state of law, the three basic principles always apply, namely supremacy of law, equality before the law, and law enforcement in a way that is not against the law. Human thinking about the state of law is born and developed in a welfare situation. Therefore, even though the concept of the state of law is considered a universal concept, at the level of implementation it turns out that it has various characteristics. It is because of the welfare situation, in addition to the influence of the nation's philosophy, state ideology and others. $^{8}$

Autonomy is a pattern of self-government. Meanwhile, regional autonomy is the regional governments' right, authority, and obligation to regulate and manage their own household in accordance with the applicable legislations. ${ }^{9}$ Based on Regional Regulation Number 3 of 2015 concerning Public Order and Peace, it is explained that the Civil Service Police Unit, hereinafter abbreviated as Satpol PP, is part of the regional apparatus in upholding Regional Regulations and organizing public order and peace; The Civil Service Police are members of Satpol PP as Regional Government apparatus in upholding Regional Regulations and organizing public order and peace; and public order and peace is a dynamic condition allowing the Government, Regional Government and the society to carry out their activities in a peaceful and orderly manner.

According to Government Regulation Number 31 of 1980 concerning Derelicts and Beggars Handling, it is explained that beggars are people who earn money by asking to publics in various ways for expecting mercy from others, while derelicts are people who live in a situation that is not in accordance with the norms of decent living in the local society, and does not have a permanent place to live and work in certain areas and live wandering in public places. Authority, according to Miriam Budihardjo, is the ability of a person or group of people/humans to influence someone's behavior or another group in such a way so that

Bahder Johan Nasution, Negara Hukum dan Hak Asasi Manusia, Mandar Maju, Bandung, 2012, pp. 19.

Munir Fuady, Op.Cit., pp. 79.

Departemen Pendidikan Nasional, Kamus Besar Bahasa Indonesia Pusat Bahasa, PT. Gramedia Pustaka Utama, Jakarta, 2008, pp. 992. 
the behavior is in accordance with the wishes and goals of the person or country. ${ }^{10}$ In relation to this, the authority of the Civil Service Police Unit in handling PGOT issues based on Regional Regulation Number 3 of 2015 is related to the things described in Chapter VIII Article 28-30 of Social Order, as follows:

a. Every person and/or institution is prohibited from asking for donations done individually and/or in group on the streets, markets, public transportations, residential neighborhoods, hospitals, schools, offices and places of worship.

b. Requests for donations for social and humanitarian purposes can only be done after obtaining permission from the District Head or the appointed officials.

c. Everyone is prohibited to:

1) Become buskers, hawkers, and/or car washers on the streets, intersections and/or certain areas that are stipulated by the District Head.

2) Coordinate people to become buskers, hawkers, and/or car washers.

3) Conduct activities as scavengers who carry out their activities at night.

d. Everyone is prohibited to:

1) Conduct activities as beggars

2) Coordinate people to become beggars.

3) Exploit children and/or babies to become beggars.

e. Everyone is prohibited from behaving and/or acting immoral on streets, green lines, parks or other public places.

Government Regulation of the Republic of Indonesia Number 6 of 2010 concerning the Civil Service Police Unit explains that the authorities of the Civil Service Police are as follows:

a. Conducting non-judicial enforcement actions against society members, apparatus, or legal entities violating local regulations and/or regional head regulations.

b. Taking actions on citizens, apparatus, or legal entities that disrupt public orderliness and peace.

c. Facilitating and empowering society protection capacities.

d. Conducting investigative actions against society members, apparatus, or legal entities alleged to have violated the

10 Miriam Budiardjo, Dasar-Dasar Ilmu Politik, Gramedia Pustaka Utama, Jakarta, 2007, hal. 35.
Regional Regulation and/or regional head regulations.

e. Conducting administrative actions against society members, apparatus, or legal entities violating local regulations and/or regional head regulations.

Based on the description, it can be stated that the authority of the Civil Service Police Unit in handling PGOT issues based on Regional Regulation Number 3 of 2015 is repressive where the discipline actions are only in the form of non-judicial acts towards beggars, vagabonds and derelicts. Furthermore, the persuasive approach becomes family's responsibility to instill independent life which does not depend on other's giving as well as provide adequate education both formally and religiously. In addition, the role of government through the Office of Social Affairs is strongly needed, especially in providing socialization, coaching, and skills improvement at Training Centers (BLK).

Factors Inhibiting the Civil Service Police Unit in Handling Beggars, Vagabonds and Derelicts (PGOT) in Kuningan District

Based on the results of survey and observation, it was found several factors causing the occurrence of beggars, vagabonds and derelicts (PGOT). Some of these factors include factors existing in the internal individuals and families, internal society, and external society, namely in the destination cities of PGOT. The factors causing the existence of beggars, vagabonds and derelicts can be described as follows:

1) Internal Factors

Internal and family factors refer to a condition within the individual and PGOT's family who encourage them to carry out activities of begging. These factors are described briefly below.

a) Individuals and Families Poverty, Individual poverty is one of the factors causing the occurrence of begging. Poverty, that occurs and is passed on by parents, causes individuals and families to become derelicts and beggars to survive. This is also due to the livelihoods of poor people in which most of them are agricultural laborers whose monthly incomes are very low under the regional minimum wage (UMR). 
b) Age, It turns out that the age factor has a significant effect in which the majority of the derelicts and beggars found are very young; under 13 years old. This young age factor provides an opportunity for them to carry out begging activities because they have no shame. Even they look cheerfully running around and joking with their friends when they are begging. This condition is very different from those who have entered adolescence, where PGOT aged between 15-40 years are rarely found.

c) Formal Education, With regard to the age factors mentioned above, it turns out that educational factors also influence a person to carry out begging activities. At the age level categorized as children, they should be attending formal education at school. However, they choose to be PGOT compared to going to school because they do not have the financial capacity for school as a result of their parents' poverty. Uneducated people do not have chances to gain knowledge or understanding about manners, religion and other sciences that inspire them to not to do activities as PGOT.

d) Parents' permission, Children who carry out begging activities have received permission from their parents or they are even told to do so. The reason is because the socio-economic conditions of the parents are very poor so that they let their children and instruct them to participate in seeking income to fulfill the needs of their household.

e) Low skills, Much of PGOT are still young. They should be enjoying academic activities or in education world. Meanwhile, those who are classified as relatively older have never received skills education. Therefore, begging activity is the easiest choice to be carried out in order to earn income easily. Yet, according to them, begging is sometimes a little difficult to be done because they have to go around and try to beg where not all prospective donators immediately give it and do not even care about it.

f) Mental attitude, This condition happens because PGOTs think that their work is something mediocre, just like any other work that aims to earn money. The absence of income sources, the limited control over productive infrastructure and facilities as well as the limited skills cause them to make begging as a job. Besides, they also said that there is no other way to get money to fulfill their needs.

In addition, this mental attitude is also driven by the lack of society's control or there is a permissive impression towards begging carried out by beggars because of their very limited economic conditions. Meanwhile, on the other hand, there is no short-term solution provided to handle this issue.

2) External/Environmental Factors

a) Limited Access to Information and Business Capital, There are limitations in accessing good information relating to various aspects of productive, social and other aspects of economy. Limitations in accessing this information are also exacerbated by the limited ownership of media infrastructure, such as television, newspapers, etc. Other access that is difficult to obtain is business capital. This situation happens because obtaining business capital requires some very difficult conditions, especially for PGOT family. The main requirement needed is the collateral in the form of a land certificate. Meanwhile, PGOT families do not dare to give their land certificates as collateral because they do not want to take the worst risk if their businesses are not successful.

b) Permissive Conditions in the Destination City, The permissive attitude of townspeople can be seen from their habits to give money to beggars, both those who come to home, on the street, in the stalls, etc. The feelings of pity, caring and sharing among human beings cause the society to give their alms to beggars. Meanwhile, on the other hand, these views are properly utilized by beggars to continue begging. The permissive attitudes are also seen from allowing beggars to pass through certain areas, such as around their homes or in public places. It is because societies do not have the right or obligation to reprimand or even arrest them.

c) Weak handling of PGOT, Even though the government has tried their best efforts in dealing with PGOT, the results have not been maximized. This condition can be seen from the presence of PGOTs who have been arrested and returned to their area of origin, but they will always be back to do 
their activities. Besides being arrested, PGOT also get coaching, but it turns out that they will be back to do their begging activities. Therefore, it can be seen that the handling of PGOT has not been effective. In addition, even though the Civil Service Police Unit often controls PGOT, their efforts have not given a deterrent effect on PGOT so that PGOT will always be back to do their activities after being arrested and coached.

Soerjono Soekanto explains that in the sociology of law, the problem of compliance or legal compliance towards legal principles has become a major factor in measuring whether or not something stipulated in the law is effective. Legal effectiveness theory, according to Soerjono Soekanto, describes that the effectiveness or failure of a law is determined by five factors, namely ${ }^{11}: 1$ ) its own legal factors (laws), 2) law enforcement factors, namely those who form or implement the law, 3 ) facilities or infrastructure factors that support law enforcement, 4) society factors, namely the environment in which the law applies or is applied, and 5) cultural factors, namely a result of work, creativity and sense based on human intentions in their relationship. ${ }^{12}$ In Kuningan District, there are some factors inhibiting the Civil Service Police Unit in handling PGOT. The barriers that are often faced by the Civil Service Police Unit of Kuningan District in handling PGOT are beggars, vagabonds and derelicts know in advance when the Civil Service Police Unit car arrives and after the Civil Service Police Unit car leaves, they continue their activities. ${ }^{13}$ In handling PGOT, the Civil Service Police Unit found that there are still old faces that had been raided. ${ }^{14}$

Based on the description, it can be concluded that there are some barriers faced by the Civil Service Police Unit in handling beggars, vagabonds and derelicts. Handling PGOT cannot be done in half. Otherwise, the

\footnotetext{
11 Suwari Suwari Akhmaddhian (2016). Penegakan Hukum Lingkungan Dan Pengaruhnya Terhadap Pertumbuhan Ekonomi Di Indonesia (Studi Kebakaran Hutan Tahun 2015). UNIFIKASI : Jurnal Ilmu Hukum. 3(1).pp.1-35

${ }^{12}$ Soerjono Soekanto, Efektivitas Hukum dan Peranan Saksi, Remaja Karya, Bandung, 2010, hal. 7.

${ }^{13}$ Interview results with Ika Hegiana, Satpol PP Kabupaten Kuningan, 17 May 2017.

${ }^{14}$ Interview results with Hendrayana, Kepala Seksi Operasi dan Pengendalian Satuan Polisi Pamong Praja Kabupaten Kuningan, 17 May 2017.
}

government should control it completely so that public orderliness and peace can be realized.

In implementing Regional Regulation Number 3 of 2015 concerning Public Orderliness and Peace, the Civil Service Police Unit experiences financial constraints or lack of funds to support the implementation of PGOT handling. As explained by the Finance Section of the Civil Service Police Unit of Kuningan District that in order to handle beggars, vagabonds and derelicts, the Civil Service Police Unit experiences problems in the form of lack of funds from APBD so that it affects office activities. ${ }^{15}$

Another barrier faced by the Civil Service Police Unit in handling PGOT in Kuningan District is a finding of PGOTs who have been raided or old faces. This should not happen, if control and guidance given to PGOT are appropriate and supported by funds to be more effective in handling PGOT (beggars, vagabonds and derelicts). The observations in the field showed that there is another barrier faced by the Civil Service Police Unit in handling PGOT in Kuningan District, namely the absence of a shelter for PGOT that was raided so that PGOT can still carry out their daily activities in Kuningan District. Based on the description, the factors inhibiting the Civil Service Police Unit in handling PGOT in Kuningan District can be summarized in the following table.

Table 1. Factors Inhibiting the Civil Service Police Unit in Handling Beggars, Vagabonds and Derelicts (PGOT) in Kuningan District.

\begin{tabular}{|cll|}
\hline No. & \multicolumn{1}{c|}{ Barriers } & \multicolumn{1}{c|}{ Descriptions } \\
\hline 1 & $\begin{array}{l}\text { Know when the Civil } \\
\text { Service Police Unit car } \\
\text { comes to discipline } \\
\text { PGOT }\end{array}$ & $\begin{array}{l}\text { Beggars, vagabonds and } \\
\text { derelicts run when they see } \\
\text { the Civil Service Police Unit } \\
\text { car }\end{array}$ \\
\hline 2 & $\begin{array}{l}\text { PGOTs are repeatedly } \\
\text { raided }\end{array}$ & $\begin{array}{l}\text { Guidance for beggars, } \\
\text { vagabonds and derelicts has } \\
\text { been done, but they return to } \\
\text { do their activities }\end{array}$ \\
\hline 3 & Lack of APBD funds & $\begin{array}{l}\text { The allocated APBD is not } \\
\text { enough to handle PGOT } \\
\text { issues }\end{array}$ \\
\hline 4 & $\begin{array}{l}\text { There is no shelter for } \\
\text { PGOT }\end{array}$ & $\begin{array}{l}\text { There is no temporary shelter } \\
\text { for training beggars, } \\
\text { vagabonds and derelicts so } \\
\text { that they still carry out their } \\
\text { daily activities in Kuningan } \\
\text { District }\end{array}$ \\
& & \\
\end{tabular}

Source: Research Results (2017)

Interview results with Bapak Edi, Bagian Keuangan Satpol PP Kabupaten Kuningan, 18 May 2017. 


\section{CONCLUSION}

Based on the analysis and discussion results, it can be concluded that:

a. Authority, according to Miriam Budihardjo, is the ability of a person or group of people/humans to influence someone's behavior or another group in such a way so that the behavior is in accordance with the wishes and goals of the person or country. The authority of the Civil Service Police Unit in handling PGOT (Beggars, vagabonds and derelicts) issues based on Regional Regulation Number 3 of 2015 is as an organizer of public orderliness and peace relating to social orderliness as stipulated in Article 28-30 of Regional Regulation Number 03 of 2015 concerning Public Order and Peace.

b. Legal effectiveness theory, according to Soerjono Soekanto, describes that the effectiveness or failure of a law is determined by five factors, namely: 1) its own legal factors (laws), 2) law enforcement factors, namely those who form or implement the law, 3) facilities or infrastructure factors that support law enforcement, 4) society factors, namely the environment in which the law applies or is applied, and 5) cultural factors, namely a result of work, creativity and sense based on human intentions in their relationship. The factors inhibiting the Civil Service Police Unit in handling PGOT in Kuningan District, namely internal and external factors, such as PGOT knows when the Civil Service Police Unit's car comes to discipline them, PGOTs are repeatedly raided, lack of APBD funds, and there is no shelter for PGOT.

\section{SUGGESTION}

Based on the conclusions, the suggestions that can be provided to the parties related to this research are as follows:

a. Regional Government

1) The Regional Government of Kuningan District should build supporting facilities, such as rehabilitation facilities for beggars, vagabonds and derelicts supported by adequate funds so that it can help the Civil Service Police Unit in handling PGOT issues.

2) Regulation related to the prohibition on providing food or money to beggars, vagabonds and derelicts, completed by strict sanctions against people who violate the regional regulation.

b. Society

Society participation is needed to educate beggars, vagabonds and derelicts to not to depend on others' giving by providing job opportunities so that beggars, vagabonds and derelicts can live independently.

\section{REFERENCES}

\section{A. Books, Journals}

Bahder Johan Nasution, (2012) Negara Hukum Dan Hak Asasi Manusia, Mandar Maju, Bandung.

Departemen Pendidikan Nasional. (2008). Kamus Besar Bahasa Indonesia Pusat Bahasa, PT. Gramedia Pustaka Utama, Jakarta.

Dirjen Pemerintahan Umum .(2005). Pedoman Prosedur Tetap Operasional Satuan Polisi Pamong Praja, Departemen Dalam Negeri, Jakarta.

Irawan Soejito (2010). Sejarah Daerah Indonesia, Pradanya Paramita, Jakarta.

Miriam Budiardjo . (2007). Dasar-Dasar Ilmu Politik, Gramedia Pustaka Utama, Jakarta.

Moh. Kusnardi dan Harmaily Ibrahim. (2009). Hukum Tata Negara Indonesia, Sinar Bakti, Jakarta.

Soerjono Soekanto. (2010). Efektivitas Hukum dan Peranan Saksi, Remaja Karya, Bandung.

Suwari Akhmaddhian dan Anthon Fathanudien (2015). Partisipasi Masyarakat dalam Mewujudkan Kuningan sebagai Kabupaten Konservasi (Studi di Kabupaten Kuningan). UNIFIKASI : Jurnal Ilmu Hukum. 2(1).pp.67-90.

Suwari Akhmaddhian (2016). Penegakan Hukum Lingkungan Dan Pengaruhnya Terhadap Pertumbuhan Ekonomi Di Indonesia (Studi Kebakaran Hutan Tahun 2015). UNIFIKASI : Jurnal Ilmu Hukum. 3(1).pp.1-35

The Liang Gie. (2007). Pertumbuhan Pemerintahan Daerah di Republik Indonesia, Liberty, Yogyakarta.

Wojowasito, Kamus Umum Belanda Indonesia, PT Ichtiar Baru Van Hoeve, Jakarta, 2003. 


\section{B. Legislations}

Undang-Undang Dasar Negara Republik Indonesia Tahun 1945.

Undang-Undang Republik Indonesia Nomor 23 Tahun 2014 tentang Pemerintahan Daerah.

Peraturan Pemerintah Republik Indonesia Nomor 31 Tahun 1980 tentang Penanggulangan Gelandangan dan Pengemis.

Peraturan Pemerintah Republik Indonesia Nomor 6 Tahun 2010 tentang Satuan Polisi Pamong Praja.

Peraturan Daerah Kabupaten Kuningan Nomor 3 Tahun 2015 tentang Penyelenggaraan Ketertiban Umum dan Ketentraman Masyarakat termasuk dalam penanganan Pengemis, Gelandangan dan Orang Terlantar (PGOT). 